\title{
Controlled foreign companies of Russian residents in the context of world trends
}

\author{
Evgenia E. Frolova $₫$, Ekaterina A. Tsepova \\ Peoples' Friendship University of Russia (RUDN University), Moscow, Russian Federation \\ \rolova_ee@rudn.ru
}

\begin{abstract}
The subject of this article is financial relations of the state and its tax residents with foreign assets (stock), as well as control over such companies through various legal mechanisms. The authors examined the main global trends in the development of legislation on controlled foreign corporations, as well as characteristics of tax systems that may contribute to such norms introduction. It was found that implementation of international multilateral agreements such as CRS MCAA and CBC MCAA in the field of tax control enhances development of anti-offshore regulation, including legislation on controlled foreign corporations. Particular attention is paid to the comparative legal analysis of the controlled foreign companies' (CFC) rules in 15 jurisdictions, including the Russian Federation and identification of similar and specific rules. As a result of the research, the authors came to the conclusion that Russia is following the world trends, although at this stage it is not the country that forms them. In the future, to successfully apply the CFC legislation in the Russian Federation, it will be necessary to improve the existing norms $s_{2}$ increase the efficiency of tax administration and improve the legal status of taxpayers.
\end{abstract}

Key words: controlled foreign corporation, CFC, resident, tax transparency, CRS, CRS MCAA, CBC MCAA, overseas assets, tax liabilities

Conflict of interest. The authors declare no conflict of interest.

The participation of the authors: inseparable co-authorship.

Funding information. This work was financially supported by Grant of the President of the Russian Federation No. HШ-2668-2020.6 "National-Cultural and Digital Trends in the Socio-Economic, Political and Legal Development of the Russian Federation in the 21st Century".

Article received 17th September 2021

Article accepted 15th October 2021

\section{For citation:}

Frolova, E.E., Tsepova, E.A. (2021) Controlled foreign companies of Russian residents in the context of world trends. RUDN Journal of Law. 25 (4), 814-830. DOI: 10.22363/2313-23372021-25-4-814-830

(C) Frolova E.E., Tsepova E.A., 2021

This work is licensed under a Creative Commons Attribution 4.0 International License

https://creativecommons.org/licenses/by/4.0 


\title{
Контролируемые иностранные компании российских резидентов в контексте мировых тенденций
}

\author{
Е.Е. Фролова $\mathbb{D} \triangle$, Е.А. Цепова \\ Российский университет дружбы народов, г. Москва, Российская Федерация \\ \frolova_ee@rudn.ru
}

\begin{abstract}
Аннотация. Предметом исследования статьи являются финансово-правовые отношения между государством и его налоговыми резидентами, связанные с наличием у них в собственности долей и акций иностранных компаний, а также с возможностью осуществлять контроль над такими компаниями посредством иных юридических механизмов. В ходе исследования авторами рассмотрены основные мировые тенденции сфере развития законодательства о контролируемых иностранных компаниях, а также характеристики налоговых систем, которые могут способствовать введению указанных норм. Кроме того, установлено, что реализация международных многосторонних соглашений в сфере налогового контроля, таких как CRS MCAA и CBC MCAA, усиливает развитие антиофшорного регулирования, в том числе законодательства о контролируемых иностранных компаниях. Особое внимание уделено сравнительно-правовому анализу норм о контролируемых иностранных компаниях в 15 юрисдикциях, включая Российскую Федерацию, выявлению схожих и специфических норм права. В результате исследования авторы пришли к выводу, что Россия следует мировым тенденциям, хотя на данном этапе и не является страной, которая их формирует. В дальнейшем для успешного применения в Российской Федерации законодательства о КИК потребуется совершенствование действующих норм в целях повышения эффективности налогового администрирования и улучшения правового положения налогоплательщиков.

Ключевые слова: контролируемая иностранная компания, КИК, резидент, налоговая прозрачность, CRS, CRS MCAA, CBC MCAA, активы за рубежом, налоговые обязательства

Конфликт интересов. Авторы заявляют об отсутствии конфликта интересов.

Информация о вкладе авторов: нераздельное соавторство.

Информация о финансировании. Исследование выполнено при финансовой поддержке Гранта Президента Российской Федерации № НШ-2668-2020.6 «Национально-культурные и цифровые тенденции социально-экономического, политического и правового развития Российской Федерации в XXI веке».
\end{abstract}

Дата поступления в редакиию: 17 сентября 2021 г.

Дата принятия к печати: 15 октября 2021 г.

\section{Для цитирования:}

Frolova E.E., Tsepova E.A. Controlled foreign companies of Russian residents in the context of world trends // RUDN Journal of Law. 2021. T. 25. № 4. C. 814 -830. DOI: 10.22363/23132337-2021-25-4-814-830

\section{Introduction}

Strengthening of fiscal control over taxpayers ' cross-border transactions is one of the key areas for the development of global tax practice. Particular attention is focused on such problems as possibility of a taxpayer to choose a country in which the income is taxed (Hilling, 2013), exclusion of certain types of income received from 
foreign sources from the tax base (Avi-Yonah, 2005), tax evasion by performing cross-border financial transactions and withdrawing funds to offshore zones (Mara, 2015; Morten \& Zeume 2018). As a result, the mechanisms for realization of state's rights are constantly being improved due to technical progress and development of international and domestic legislations, which endows tax authorities with new opportunities and taxpayers with new responsibilities.

This trend is also observed in the development of Russian tax law. Deoffshorization of the Russian economy has reached a completely new level with the entry into force of the Federal Law No. 376-FZ of November 24, 2014 "On amendments to parts one and two of the Tax Code of the Russian Federation (in terms of taxation of profits of controlled foreign corporations and income of foreign organizations)", which introduced into the tax legislation the term "Controlled foreign company" (CFC). A CFC, as a legal structure, is a legal entity operating in the jurisdiction of one state but owned or controlled by tax residents of another state. In its recommendations the Organization for Economic Co-operation and Development (OECD) highlights legal control, which is implemented through the right to elect or appoint the executive bodies of the organization, to exercise economic control as the right to receive capital or other property of the company, and de facto control a set of conditions that allow a tax resident to exert a decisive influence on the company's activities $^{1}$.

Conducting business using controlled foreign organizations has gained popularity among taxpayers, primarily in developed countries, for several reasons: first of all, confidentiality that in some cases can be ensured by the ownership of assets through a CFC; secondly, the possibility of saving on taxation when making transactions with foreign assets; thirdly, the ability to take the company's activities out of the framework of strict domestic legislation, for example, in the field of financial market rules, protection of intellectual rights or currency exchange regulation.

For this reason, in a number of countries (primarily developed ones) residents controlling persons of foreign organizations - have obligations to pay tax on profits received by a foreign company, as well as to notify tax authorities about participation in foreign organizations. They are aimed at ensuring fair taxation and preventing withdrawal of income from countries with a high tax rate (Rust, 2008).

It is of interest to study global practices of applying legal mechanisms aimed at preventing tax evasion by transferring income from the country of tax residence to countries with a lower tax burden, in particular, CFC rules. It is also important to consider the impact of international tax transparency on financial relations between a state and its tax residents who own assets abroad (Meyer, 2013; Morris, 2017; Noked, 2018a). The study of Russian legislation on controlled foreign companies in the context of global trends will expand the existing scientific views on the norms of anti-offshore regulation; it will also contribute to the improvement of legal mechanisms in this area.

\footnotetext{
${ }^{1}$ OECD 2015. Designing Effective Controlled Foreign Company Rules, Action 3 - 2015 Final Report. Available at: http://dx.doi.org/10.1787/9789264241152-en [Accessed 02nd September 2021].
} 


\section{Aims and Methodology}

The general methodological idea of this article is to outline the content of global trends in the development of legislation on controlled foreign companies and then determine whether Russian legislation in this area follows these trends. Another relevant issue is the prospects for legislation development in this country.

This article provides a comparative analysis of the norms of financial regulation of relations with residents who are controlling persons of foreign organizations in countries with different levels of economic development. The performed analysis best be characterized by the term "functional comparison" (Bogdan, 2013; Schmidt, 2016) in relation to a specific legal problem, namely, how different jurisdictions try to solve the problem of taxpayers' tax evasion through withdrawal of income to low-tax jurisdictions.

Firstly, the specifics of the tax system in 15 states with different levels of economic development applying the CFC rules, as well as different geopolitical characteristics were considered in order to identify common prerequisites for the emergence and development of these rules (Owens, 2015; Morten \& Zeume, 2018). Some studies of tax systems, which are more generalized, show that at the global level there is a clear relationship between the degree of economic development of a country and methods of regulating relations with residents owning capital in other jurisdictions (Tsepova, 2020; Frolova \& Tsepova, 2020; Frolova \& Tsepova 2021).

To optimize the results presentation, the analysis is based on the following indicators:

1) The place of the state in the estimated GDP per capita ranking for $2020^{2}$.

2) The state's involvement in the development of effective measures to combat crime in the financial sector, which is characterized by membership in international organizations such as the Organisation for Economic Co-operation and Development ${ }^{3}$ or the Financial Action Task Force on Money Laundering 4 .

3) The interest in creating a unified global field of financial control over the movement of assets and distribution of corporate income. Participation of the state in Multilateral Competent Authority Agreement (MCAA) on Automatic Exchange of Financial Account Information (CRS MCAA) ${ }^{5}$ and MCAA on the Exchange of Country-by-Country Reports (CBC MCAA $)^{6}$ was chosen as indicators.

4) According to many authors, the high tax burden in the state of tax residence is the most compelling reason for taxpayers to create mechanisms of tax base erosion, and incorporation of a CFC in low-tax jurisdictions is one of them (Mara 2015; Eden \&

\footnotetext{
${ }^{2}$ International Monetary Fund. World Economic Outlook Database, April 2021 Edition. Available at: https://www.imf.org/en/Publications/WEO/weo-database/2021/April/select-country-group [Accessed 20th August 2021].

${ }^{3}$ OECD 2021. Member countries. Available at: https://www.oecd.org/about/members-and-partners/ [Accessed 27th August 2021].

${ }^{4}$ FATF 2021. FATF Members and Observers. Available at https://www.fatf-gafi.org/about/ membersandobservers/ [Accessed 23rd August 2021].

${ }^{5}$ OECD 2021. List of CRS MCAA signatories. Available at: http://www.oecd.org/tax/automatic-exchange/ international-framework-for-the-crs/MCAA-Signatories.pdf [Accessed 23rd August 2021].

${ }^{6}$ OECD 2021. List of CbC MCAA signatories. Available at: https://www.oecd.org/tax/automatic-exchange/ about-automatic-exchange/CbC-MCAA-Signatories.pdf [Accessed 23rd August 2021].
} 
Kudrle, 2005). For this reason, the Corporate Tax Rate was chosen as another criterion (Asen, 2020).

Secondly, a comparative legal analysis (Eberle, 2011) of the main characteristics of the CFC legislation in selected countries was carried out. In particular, the criteria for recognizing a resident of the country as a controlling person of a foreign organization, the minimum size of residents' (individuals and legal entities) participation share in the capital of a foreign organization for its recognition as a CFC, as well as the basic principles of limiting the CFC rules have been considered.

In addition to the specifics of Russian legislation, special attention is paid to US tax regulations. According to some authors, the United States is recognized as the main "trendsetter" of new international ways in taxation. One of the examples illustrating this statement is adopting in 1962 the CFC rules that later became widespread in many countries (Avi-Yonah, 2016).

Thirdly, applying the content analysis, we investigated the changes in Russian tax legislation that came into force in 2021 in order to identify the latest trends in the development of the CFC legislation.

Considering the limited format of this article, a full analysis of anti-offshore regulation methods forming a wide group of legal norms, including CFC rules, transfer pricing rules, concept of the beneficial owner of income, thin capitalization rules and others concerning each of the states under study has been left aside.

Instead, we focus on an overview of the current CFC legislation, which can provide a sufficient basis for:

1) assessing the prerequisites for the emergence and prospects for the development of the relevant norms in a particular state,

2) identifying similar and distinctive characteristics in the approach used by the Russian Federation and other states,

3) analysis of the prospects for improving the domestic regulatory framework in this area.

\section{Results}

We provide a brief description of the tax system in the countries under review (see Table 1) in terms of prerequisites for the development of CFC legislation.

The data demonstrate the relationship between the degree of a country's economic development and the methods of regulating relations with residents owning capital in other jurisdictions. Developed countries are also more active in introducing new methods of countering tax evasion, e.g., anti-offshore regulations.

Countries with high-ranking positions are characterized by a better developed system of tax control. These states are actively fighting tax evasion by withdrawing capital to jurisdictions with a lower tax burden. They do not only strengthen domestic financial control, but also develop cooperation with international organizations such as the OECD and the FATF. As a result, they expand the boundaries of international tax transparency. Not only developed countries, but also countries with developing and transitional economies have joined the CRS MCAA and CBC MCAA by now. 
Table 1. Main characteristics of the tax system of 15 jurisdictions applying the CFC rules, distributed by GDP per capita ranking for $2020^{7}$

\begin{tabular}{|c|c|c|c|c|c|c|}
\hline Rank & State & $\begin{array}{c}\text { GDP per capita, US } \\
\text { dollars/person, 2020 }\end{array}$ & $\begin{array}{c}\text { Member } \\
\text { of the OECD } \\
\text { or FATF }\end{array}$ & $\begin{array}{c}\text { Member } \\
\text { of CRS } \\
\text { MCAA }\end{array}$ & $\begin{array}{c}\text { Member } \\
\text { of CBC } \\
\text { MCAA }\end{array}$ & $\begin{array}{c}\text { Corporate } \\
\text { Tax Rate }\end{array}$ \\
\hline 1 & Luxembourg & 118002 & $\checkmark$ & $\checkmark$ & $\checkmark$ & $24,94 \%$ \\
\hline 7 & USA & 63416 & $\checkmark$ & & & $25,77 \%$ \\
\hline 16 & Germany & 54076 & $\checkmark$ & $\checkmark$ & $\checkmark$ & $29,90 \%$ \\
\hline 21 & Canada & 48720 & $\checkmark$ & $\checkmark$ & $\checkmark$ & $26,47 \%$ \\
\hline 23 & France & 46062 & $\checkmark$ & $\checkmark$ & $\checkmark$ & $32,02 \%$ \\
\hline 25 & United Kingdom & 44117 & $\checkmark$ & $\checkmark$ & $\checkmark$ & $19,00 \%$ \\
\hline 27 & Japan & 42248 & $\checkmark$ & $\checkmark$ & $\checkmark$ & $29,74 \%$ \\
\hline 36 & Spain & 38392 & $\checkmark$ & $\checkmark$ & $\checkmark$ & $25 \%$ \\
\hline 49 & Russia & 27930 & $\checkmark$ & $\checkmark$ & $\checkmark$ & $20 \%$ \\
\hline 52 & Kazakhstan & 26565 & & $\checkmark$ & $\checkmark$ & $20 \%$ \\
\hline 55 & Bulgaria & 23817 & & $\checkmark$ & $\checkmark$ & $10 \%$ \\
\hline 72 & China & 17192 & $\checkmark$ & $\checkmark$ & $\checkmark$ & $25 \%$ \\
\hline 80 & $\varnothing$ Brazil & 14916 & $\checkmark$ & $\checkmark$ & $\checkmark$ & $34 \%$ \\
\hline 96 & Indonesia & 12222 & $\checkmark$ & $\checkmark$ & $\checkmark$ & $25 \%$ \\
\hline 98 & Douth Africa & 12032 & $\checkmark$ & $\checkmark$ & $\checkmark$ & $28 \%$ \\
\hline
\end{tabular}

Of the developed countries only the United States of America has not joined CRS MCAA and CBC MCAA; however, the international exchange of financial information with this state is carried out in accordance with US Law No. 111-147 dated March 18, 2010.

With its adoption, the amendments were made to the US Tax Code collectively referred to as the Foreign Account Tax Compliance Act (FATCA), which came into effect much earlier than the CRS $\mathrm{MCAA}^{8}$. The subjects of FATCA regulation are foreign organizations of the financial market, which are responsible for informing the US Internal Revenue Service about the accounts of US taxpayers. In case of failure to comply with this requirement, their activities are subject to taxation at the rate of 30 percent of the turnover on correspondent accounts opened with US banks, which virtually makes operation of such organizations in the US impossible without fulfilling the FATCA requirements (Noked, 2018b; Tsepova, 2019: 45).

The study data also shows that the high corporate tax rate is a significant but not the only reason for introducing CFC legislation. For example, such rules are applied in Bulgaria - a country with one of the lowest corporate tax rates in the world. Thus, it can be assumed that in some cases the choice may be due to other factors, such as pressure from the international community or desire to demonstrate that the tax system of the state is keeping up with the times.

\footnotetext{
${ }^{7}$ International Monetary Fund. World Economic Outlook Database, April 2021 Edition. Available at: https://www.imf.org/en/Publications/WEO/weo-database/2021/April/select-country-group [Accessed 20th August 2021].

${ }^{8}$ United States Government. Public Law «Hiring Incentives to Restore Employment Act». March 18, 2010 No. 111-147. Washington, USA.
} 
The legal structure of a controlled foreign corporation appeared for the first time in the regulatory framework of the United States. With enforcing Public Law 87-834 «Revenue Act of 1962», the Subpart F «Controlled Foreign Corporations» was added to the US Tax Code'.

In accordance with paragraph 6046 of this Subpart, American shareholders who, directly or indirectly, own more than $10 \%$ of the voting shares (or share capital) of a foreign organization (and in total, American shareholders own more than $50 \%$ of the voting shares or share capital), are required to inform the Internal Revenue Service of the United States about their share of a foreign organization, as well as to declare and pay taxes on the amounts of certain types of income of this legal entity, such as dividends, interest, royalties, rent payments, annuities, and income from the sale of property that generates such "passive" income. The financial regulation of the United States in this area to this day remains one of the most stringent in the world (Tsepova, 2019).

Later, legal regulation of tax liabilities of residents with shares in capital of foreign organizations developed in the United States began to be adopted by other states with some alterations (mainly, with certain mitigations). To identify patterns in regulation of such legal relations, let us investigate the features of the CFC legislation in the states under study (see Table 2).

The data study reveals a number of common characteristics in regulation: in all considered jurisdictions, legal and / or economic control is a criterion for recognizing residents as controlling persons of a foreign organization. At the same time, the share of both direct and indirect participation of a resident in a foreign organization is taken into account as a criterion for legal control. In some countries, including the Russian Federation, CFC legislation also provides for de facto control as an independent basis for recognizing a resident as a controlling person of a foreign company, for example, if the resident is a party to an agreement to manage the foreign company.

The above characteristics are largely due to the impact of the OECD recommendations on harmonization of domestic legislation ${ }^{10}$ and the Action Plan on Base Erosion and Profit Shifting (BEPS) ${ }^{11}$, whose publication entailed amendments to $\mathrm{CFC}$ rules in many countries.

Considering the above recommendations, most jurisdictions set $50 \%$ as a threshold value for the share of residents' participation in a foreign company to be recognized as controlled. At the same time, in many countries such value is set as above $10 \%$ (USA, Japan, Brazil, Russian Federation, China) whereas in France, the minimum resident participation rate for $\mathrm{CFC}$ rules application is $5 \%$.

At the same time, the research data show that at the domestic level there are some discrepancies in the issues of establishing control over foreign organizations, as well as in the approach to the exclusion criteria, according to which the CFC rules are not applied to a foreign company.

\footnotetext{
${ }^{9}$ United States Government. Public Law «Revenue Act of 1962» (October 16, 1962 No. 87—834). Washington, USA.

${ }^{10}$ OECD 2015. Designing Effective Controlled Foreign Company Rules, Action 3 - 2015 Final Report. Available at: http://dx.doi.org/10.1787/9789264241152-en [Accessed 02rd September 2021].

${ }^{11}$ OECD 2013. Action Plan on Base Erosion and Profit Shifting. Available at: http://dx.doi.org/10.1787/ 9789264202719-en [Accessed 03rd September 2021].
} 
Table 2. Main characteristics of application of law to controlled foreign corporations in 15 jurisdictions

\begin{tabular}{|c|c|c|c|c|c|c|}
\hline State & $\begin{array}{c}\text { Economic } \\
\text { and legal } \\
\text { control } \\
\text { over } \\
\text { a foreign } \\
\text { organization }\end{array}$ & \begin{tabular}{|c|} 
De \\
facto \\
control
\end{tabular} & $\begin{array}{c}\text { Application } \\
\text { of "white" } \\
\text { or "black" } \\
\text { list of } \\
\text { jurisdictions } \\
\text { within the } \\
\text { framework } \\
\text { of CFC rules }\end{array}$ & $\begin{array}{c}\text { Restrictions } \\
\text { on CFC } \\
\text { rules } \\
\text { in relation } \\
\text { to foreign } \\
\text { companies } \\
\text { that are tax } \\
\text { residents } \\
\text { of countries } \\
\text { with a high } \\
\text { tax burden }\end{array}$ & $\begin{array}{c}\text { Restriction } \\
\text { s on CFC } \\
\text { Rules } \\
\text { for foreign } \\
\text { companies } \\
\text { engaged } \\
\text { in certain } \\
\text { types } \\
\text { of activities }\end{array}$ & \begin{tabular}{|c|} 
The aggregate \\
share \\
of participation \\
of residents \\
(individuals \\
and legal entities) \\
in the capital \\
of a foreign \\
organization \\
to be recognized \\
as CFC
\end{tabular} \\
\hline Luxembourg & $\checkmark$ & & & $\checkmark$ & & More than $50 \%$ \\
\hline USA & $\checkmark$ & & & & $\bar{\checkmark}$ & More than $50 \%$ \\
\hline Germany & $\checkmark$ & & & $\bar{\checkmark}$ & $\checkmark$ & More than $50 \%$ \\
\hline$\uplus$ Canada & $\checkmark$ & & & $\checkmark$ & $\checkmark$ & More than $50 \%$ \\
\hline France & $\checkmark$ & - & $\sqrt{ }$ & $\checkmark$ & $\checkmark$ & More than $50 \%$ \\
\hline $\begin{array}{l}\text { United } \\
\text { Kingdom }\end{array}$ & $\checkmark$ & - & $\checkmark$ & $\checkmark$ & - & Not less than $25 \%$ \\
\hline - Japan & $\checkmark$ & $\checkmark$ & $\checkmark$ & $\checkmark$ & $\checkmark$ & More than $50 \%$ \\
\hline Spain & $\checkmark$ & - & - & $\checkmark$ & $\checkmark$ & More than $50 \%$ \\
\hline Russia & $\checkmark$ & $\checkmark$ & - & $\checkmark$ & $\checkmark$ & $\begin{array}{l}\text { More than } 50 \% \\
\text { for all residents } \\
\text { of the Russian } \\
\text { Federation } \\
\text { or more than } 25 \% \\
\text { for one person }\end{array}$ \\
\hline Kazakhstan & $\checkmark$ & $\checkmark$ & $\checkmark$ & $\checkmark$ & & More than $25 \%$ \\
\hline Bulgaria & $\checkmark$ & & & $\checkmark$ & $\bar{\checkmark}$ & More than $50 \%$ \\
\hline China & $\checkmark$ & $\checkmark$ & $\checkmark$ & $\checkmark$ & - & More than $50 \%$ \\
\hline$\theta$ Brazil & $\checkmark$ & - & $\checkmark$ & $\checkmark$ & - & More than $50 \%$ \\
\hline Indonesia & $\checkmark$ & $\checkmark$ & - & - & $\checkmark$ & More than $50 \%$ \\
\hline $\begin{array}{l}\text { South } \\
\text { Africa }\end{array}$ & $\checkmark$ & - & - & $\checkmark$ & - & More than $50 \%$ \\
\hline
\end{tabular}

For example, in Germany, where CFC legislation has been in effect since 1972, tax residents holding interests in foreign companies are required to pay tax on passive income of a foreign organization if, in aggregate, German residents own more than $50 \%$ of the share capital of the company. At the same time, the size of the share of each resident does not matter. The owners of both large and small shares in the company are equally obliged to include part of the CFC's income into their taxable base, in proportion to the size of their share.

Compliance with the criteria for a controlling person of a foreign organization can be established on a specific date, most often - at the end of the financial year (Germany, Brazil, Russian Federation, Indonesia), or tracked throughout the entire reporting period (USA).

In some jurisdictions both legal entities and individuals are recognized as controlling persons who are required to pay tax on CFC profits (USA, Russian 
Federation, Germany, Spain, France, Indonesia), but in some cases only legal entities have such obligation.

In the United Kingdom (the UK), where the tax liability of the owners of foreign companies`share capital was introduced into law in 1984, individuals can be treated as controlling persons of a CFC, but this circumstance will not entail legal consequences. The British regulations governing personal income tax do not establish an obligation to pay tax on the profits of a CFC. At the same time, the control over a foreign company by an individual may become the basis for recognizing the legal entities - residents associated with such individual as controlling persons of a foreign company subject to taxation on its gains. A similar approach is being taken in China and Brazil.

In most cases, the object of taxation is the profit or income of the CFC received from so-called "passive" activities (dividends, interest, royalties, rent payments, annuities), but in some cases, all the CFC income is included in the taxable base of the controlling person; for example, such rules are applied in the UK, Indonesia, and Brazil.

Generally, income tax paid by a CFC in the country of incorporation is excluded from the tax base of the controlling person. Also, in order to avoid double taxation, the CFC's profit is deducted from the tax base when paying dividends, if the tax on CFC's profit was previously paid by the controlling person.

Besides, the research data show that, in world practice, application of CFC rules is limited to improve the tax control efficiency. There are three main approaches to the application of restrictions:

1) Priority is given to the tax burden in the state of the CFC tax residence. CFC rules do not apply to foreign companies incorporated in countries where the effective corporate tax rate is comparable to or higher than in the country in which the owner of the company's capital is a resident (Tsepova 2019, 46). This can also be done through the approval of the so-called "white list" of jurisdictions, or vice versa, a "black list" of countries with a low tax burden. Among the considered countries, this approach is used in the UK, Luxembourg, Kazakhstan, China, South Africa, and Brazil.

2) The types of activities and the structure of income of a foreign organization are of prime importance. CFC rules apply to "passive" income, such as dividends, interest, royalties, lease payments, and do not apply to companies conducting active commercial activities (trade, manufacturing, construction or others). Among the states under study, this approach is adhered to by the United States, Germany, Canada, Spain, and Indonesia.

3) Both of the above factors are equally important. This approach is used in the Russian Federation, France, Japan, and Bulgaria.

It is worth emphasizing that in each of the states under consideration, not one, but a whole set of conditions for exemption of CFC profits from taxation is applied. The above classification rather demonstrates the priority in the assessment of certain factors. There are also many specific conditions for exempting a particular company from the CFC rules application, for example, the listing of CFC shares on the stock exchange (Indonesia, France) or a certain grace period after establishing a CFC or restructuring within a group of companies (the UK).

Moreover, legislation of most countries provides a minimum threshold for the value of assets or company profits, up to which the considered norms do not apply. For 
example, in Luxembourg, companies' profits that do not exceed 750000 Euros in the financial year or do not exceed $10 \%$ of the CFC's operating expenses for the period are not taxed for controlling persons. In the UK, the subject to tax is only the CFC's profit exceeding 50000 pounds sterling per year, or more than 500000 pounds sterling, provided that the amount of profit from non-active business does not exceed 50000 pounds sterling. In China, the CFC's taxable profit threshold is 5 million Yuan, and in the Russian Federation - 10 million rubles.

In some countries, the CFC minimum income criterion is used instead of the minimum profit. For example, there is a «de minimis» rule in German tax law, which exempts CFC passive income from taxation if it does not exceed $10 \%$ of the company's total income or the CFC's total income or the personal income of its German shareholder does not exceed 80000 Euros in the financial year.

Another example of this approach is Japan, where CFC legislation has been applied since 1978 and a multi-tier system for calculating corporate income tax has been established and supplemented by a set of rules for determining CFC income. The $\mathrm{CFC}$ rules do not apply if the income of the foreign company does not exceed 20 million yen, or $5 \%$ of the total income of the controlling person in the financial year.

Application of the above restrictions in the Russian Federation has its own peculiarity. On the one hand, in order to comply with the OECD recommendations, all of them are reflected in Russian tax legislation, but in world practice, the above conditions limit the occurrence of taxpayers' obligations (both basic and derivative).

In Russia, there is a tax benefit in the form of exemption from taxation of CFC profits subject to a number of conditions. At the same time, there are procedural obligations to provide documents confirming the right to exemption, which are checked by the tax authorities. The authors are of the opinion that all of the above restrictions on CFC rules should be reflected in the Russian tax legislation not as a tax benefit, but as an exception to the rules of Chapter 3.4. of the Tax Code of the Russian Federation.

It should be noted that the concept of «controlled foreign corporation» is relatively new in the world legal practice. To date, it is still absent in the regulations of many states. For example, the legislation of countries such as Singapore, Egypt, India, Kuwait, Kenya, Oman, Qatar, Vietnam, Thailand and many others does not include any obligations of residents related to their ownership of shares in foreign companies, as well as control over such companies through other legal mechanisms.

We have already stated earlier that a present regulation of financial and legal obligations of the owners of shares in the capital of foreign organizations is applied primarily by developed countries. But we can say with confidence that their number will increase in the coming years due to the urgency of developing effective measures to counter tax evasion by withdrawing part of taxpayers' income in jurisdictions with a low tax burden (Tsepova, 2019:45).

In the Russian Federation, the latest trend in the development of legislation on controlled foreign companies is tightening of regulation, especially affecting organizations that bring small profits.

This trend is demonstrated by the amendments to the Tax Code of the Russian Federation, which entered into force in $2021^{12}$. The requirement for mandatory

${ }^{12}$ Government of the Russian Federation. The Tax Code of the Russian Federation (Part One). July 31, 1998 No. 146. Moscow, Russia. 
submission of CFC financial statements to tax authorities (and in some cases an auditor's report) now applies to all companies, regardless of their financial results.

Until 2021 the submission of financial statements of CFCs with profits below the threshold value to the tax authorities was not mandatory. Moreover, the fine for failure to submit an annual notification of controlled foreign companies has increased fivefold from 100000 to 500000 rubles.

An additional fine in the amount of 1000000 rubles was also introduced for failure to submit financial statements of a CFC at the request of the tax authority. A certain mitigation of regulatory requirements was envisaged only for individuals who invest in foreign assets on a large scale and expect a CFC to receive profits exceeding 38000000 rubles per year. They now may pay a flat tax of 5000000 rubles a year, without providing the tax authorities with the reports of foreign companies controlled by them.

\section{Discussion}

Assessing the study data in the context of Russia's compliance with current international trends, it can be argued that:

Firstly, the purpose of introducing a legal structure such as a CFC into domestic tax legislation is the taxation of tax residents' gains. Thus, CFC legislation is one of the ways to "return" the tax base to the jurisdiction from which it was derived; it solves several tasks, such as deoffshorizing economy, ensuring taxation of income of tax residents at appropriate rates, counteracting tax minimization through offshore companies, minimizing risks of shortfall in tax revenues of the budget (Joscelyne \& Wentworth-May, 2012). A key component of the CFC concept is the control by the resident over the foreign company they have interest in. The OECD points out that within the framework of national legislation, the control criterion can be defined in different ways. Control should be considered both as a type and/or degree ${ }^{13}$.

CFC rules were introduced into Russian tax legislation at a time when antioffshore regulation was actively discussed at the international level and, instead of isolated cases of its application in developed countries, became widespread throughout the world in connection with the release of the Action Plan on Base Erosion and Profit Shifting ${ }^{14}$. However, this happened later than in many developed and some developing countries. For example, in China the CFC legislation was enacted in 2008 and in Brazil — in 1995 (Rocha, 2017).

Secondly, before introduction of the CFC rules, the profit received by the organization according to other branches of law (civil, corporate) could not be considered as the income of its owner until it was distributed by shareholders' decision and paid to them as dividends (Tsepova, 2019:46). Thus, anti-offshore regulations have created a new trend in the development of global tax legislation. It consists in the emergence of tax liability for one person (a controlling person of a foreign company)

\footnotetext{
${ }^{13}$ OECD 2013. Action Plan on Base Erosion and Profit Shifting. Available at: http://dx.doi.org/10.1787/ 9789264202719-en [Accessed 03rd September 2021].

${ }^{14}$ OECD 2013. Action Plan on Base Erosion and Profit Shifting. Available at: http://dx.doi.org/10.1787/ 9789264202719-en [Accessed 03rd September 2021].
} 
upon receipt of income (economic benefits) by another person (a controlled company). And such tendency is widely applied in world practice.

Currently, the US CFC legislation covers the taxation of income received from foreign companies controlled by the United States taxpayers, including both classic sources of "passive" income, such as dividends, interest, royalties, and annuities, and income from foreign company transactions committed with related persons (Isenbergh \& Wells, 2020). Besides, in 2017 the United States introduced the Global Intangible Low-Taxed Income (GILTI) (Bueltel \& Duxbury, 2021), which applies in addition to the core CFC rules set out in Subpart F of the US Tax Code and aims at taxing the excess profits of CFCs registered in jurisdictions with a low tax burden. According to the GILTI rules, taxable income includes CFC income that is not classified as «passive» but exceeds the yield of $10 \%$ of the value of tangible assets of a foreign company (Beller, 2018).

Following the USA concerning the OECD report «Tax Challenges Arising from Digitalisation - Economic Impact Assessment» ${ }^{15}$ issued for public consultation, introduction of a new Global Anti-Base Erosion rules $(\mathrm{GloBE})^{16}$ that functions by analogy with GILTI was proposed.

The GloBE rules are aimed at ensuring minimum taxation. 130 largest countries in the world (including the Russian Federation), which account for more than $90 \%$ of world GDP, supported the idea of a global minimum corporate tax of $15 \%{ }^{17}$. If the rate is lower in some countries, the tax will have to be paid in the country of the capital's origin, thus decreasing the attractiveness of low-tax jurisdictions (Arnold, 2019).

There are other examples of such approach in a world practice; for example, the CFC rules in Brazil (active since 2015) oblige Brazilian companies to pay tax on the profits of foreign companies controlled by them as indicated in their financial statements, i.e., without focusing on CFCs passive income. At the same time, they are entitled to the deduction in the amount of tax paid in the country of CFC incorporation; a reduced tax rate for some types of business is also established. Considering Brazil's high corporate tax rate, a minimum $\mathrm{CFC}$ tax rate of $25 \%$ is ensured. According to some authors, these norms are much closer to GILTI and GloBE than to the classic OECD recommendations on CFC taxation (Maydew, Marques, Porchat de Assis \& Tenenboym, 2018).

Following the global trend, Russia has joined the OECD's plan to carry out international tax reform aiming to ensure a more equitable distribution of profits of the largest international corporations, including digital companies, among various

\footnotetext{
${ }^{15}$ OECD 2020. Tax Challenges Arising from Digitalisation - Economic Impact Assessment. Available at: https://www.oecd.org/tax/beps/tax-challenges-arising-from-digitalisation-economic-impact-assessment0e3cc2d4-en.htm [Accessed 03rd September 2021].

${ }^{16}$ OECD 2019. Global Anti-Base Erosion Proposal ("GloBE”). (Pillar Two). Available at: https://www.oecd.org/ tax/beps/public-consultation-document-global-anti-base-erosion-proposal-pillar-two.pdf.pdf [Accessed 02nd September 2021].

${ }^{17}$ OECD. Members of the OECD/G20 Inclusive Framework on BEPS joining the Statement on a Two-Pillar Solution to Address the Tax Challenges Arising from the Digitalisation of the Economy as of 12 August 2021. Available at: https:/www.oecd.org/tax/beps/oecd-g20-inclusive-framework-members-joining-statementon-two-pillar-solution-to-address-tax-challenges-arising-from-digitalisation-july-2021.pdf [Accessed 02nd September 2021].
} 
countries ${ }^{18}$. This means that GloBE rules will soon be implemented into Russian tax legislation.

Thirdly, the development of legislation on controlled foreign companies is facilitated by international cooperation in the field of tax control. One of its significant results in recent years was signing the CRS MCAA, which currently includes 111 member states and territories, including Russia ${ }^{19}$.

The implementation of the agreement, without exaggeration, is a breakthrough in the field of tax control over cross-border transactions of taxpayers since it allows the tax authorities of the member states to freely and on a regular basis receive data on the accounts of their tax residents in foreign financial market organizations in an amount sufficient to monitor compliance with tax legislation (Tsepova, 2019:45). The composition and process of collecting data that are intended for subsequent transmission within the framework of automatic exchange governs the Common Reporting Standard (CRS) ${ }^{20}$, which also requires the provision of data on the accounts of organizations controlled by the taxpayer, subject to certain conditions.

Another important agreement governing the international exchange of tax information is the CBC MCAA, signed as part of implementation of the BEPS's thirteenth paragraph ${ }^{21}$.

In other words, formation of the international tax transparency gives the tax authorities of the above agreements' member states broad opportunities in the fight against tax evasion through implementation of cross-border financial transactions. (Pistone, 2014). However, such opportunities in practice depend on perfecting the legal framework and effectiveness of administering information transmitted via the international exchange (Pross, 2015). Besides, despite all the measures taken, there are certain gaps in the financial control mechanism based on application of automatic exchange of information in accordance with the CRS; therefore, at present, international tax transparency can be called partial or emerging (Morris, 2017; Noked, $2018 \mathrm{a})^{22}$. These gaps reduce the effectiveness of measures aimed at preventing crime in the financial sector, since there is an inverse relationship between tax risks and propensity of taxpayers to commit offenses (Drake, Lusch \& Stekelberg, 2019).

\footnotetext{
${ }^{18}$ OECD. Members of the OECD/G20 Inclusive Framework on BEPS joining the Statement on a Two-Pillar Solution to Address the Tax Challenges Arising from the Digitalisation of the Economy as of 12 August 2021. Available at: https://www.oecd.org/tax/beps/oecd-g20-inclusive-framework-members-joining-statementon-two-pillar-solution-to-address-tax-challenges-arising-from-digitalisation-july-2021.pdf 02nd September 2021].

${ }^{19}$ OECD 2021. List of CRS MCAA signatories. Available at: http://www.oecd.org/tax/automaticexchange/international-framework-for-the-crs/MCAA-Signatories.pdf [Accessed 23rd August 2021].

${ }^{20}$ OECD 2017. Standard for Automatic Exchange of Financial Account Information in Tax Matters, Second Edition. Available online: https://www.oecd-ilibrary.org/taxation/standard-for-automatic-exchange-offinancial-account-information-in-tax-matters-second-edition_9789264267992en;jsessionid=IW0_TZBRjv88sDJiI20E2i1C.ip-10-240-5-179 [Accessed 02 rdSeptember 2021].

${ }^{21}$ OECD 2013. Action Plan on Base Erosion and Profit Shifting. Available at: http://dx.doi.org/10.1787/ 9789264202719-en [Accessed 03rd September 2021].

22 OECD 2018. Consultation Document: Preventing Abuse of Residence by Investment Schemes to Circumvent CRS. Available at: http://www.oecd.org/tax/exchange-of-tax-information/consultation-document-preventingabuse-of-residence-by-investment-schemes.pdf [Accessed 03rd September 2021]. OECD 2018. Model Mandatory Disclosure Rules for CRS Avoidance Arrangements and Opaque Offshore Structures. Available online: http://www.oecd.org/tax/exchange-of-tax-information/model-mandatory-disclosure-rules-for-crsavoidance-arrangements-and-opaque-offshore-structures.pdf [Accessed 30th May 2019].
} 


\section{Conclusion}

The analysis of world practice shows that the main trends in the development of legislation on controlled foreign companies are:

1) popularization of these norms internationally, including not only developed countries, but countries with developing and transitional economies,

2) tightening of regulation, including higher complexity and number of procedural obligations of taxpayers, as well as emergence of new and more complex tax regimes that take into account different types of activities and structure of CFC income,

3) strengthening the role of multilateral international relations in the field of state financial control over cross-border transactions of taxpayers.

The Russian Federation confidently follows all the above trends in the field of taxation, although currently it is not the country that forms them. Summing up the findings of this article, it is necessary to resume that at the moment there are no prerequisites for this trend to be changed.

Most likely, the course of deoffshorization of the Russian economy will continue, which will lead to further tightening of the legislation on controlled foreign companies and may completely replace the possibility of doing international business for small and medium-sized Russian companies, giving preference to larger market players.

International tax transparency has a significant impact on financial legislation both internationally and domestically. The state's access to data on the accounts of its tax residents in foreign financial institutions, obtained through international automatic exchange, changes the nature of financial control from selective to continuous. The result is the massive application of the rules of financial and legal regulation in relation to tax residents who own assets in other states. In these conditions, the requirements for the quality of the legal framework in this area are significantly increasing.

In the course of CRS MCAA implementation, a completely new reliable information channel was created for the financial control authorities of the member states. As a result, other, less objective channels of information (in particular, the provision of data on financial assets by taxpayers themselves) require revision. A number of procedural duties of individuals have lost their relevance; thus, their further maintenance reduces the efficiency of information administration within the framework of state financial control due to overlapping information flows.

To solve these problems, certain changes are required to the current Russian tax legislation, namely:

- reducing the range of subjects of procedural tax liabilities arising from the rules on taxation of controlled foreign companies' profits,

- deregulating a number of procedural tax obligations of controlling persons,

- developing and implementing diversified rules governing liability of taxpayers for failure to comply with procedural obligations, depending on the status of the taxpayer (individual or legal entity) and the amount of damage caused to the state as a result of violation.

We should note that the article has not studied such important issues as:

1) analysis of other means of anti-offshore regulation, including transfer pricing rules, thin capitalization rules, and some others, 
2) methodological and practical approaches to the development of legislation on controlled foreign companies, depending on the status of the taxpayer (individual or legal entity),

3) methods for assessing the influence of other factors (political and social) on financial and legal regulation of relations with controlling persons of foreign companies.

The authors intend to get further insight into, as well as further elaborate and develop, these and some other aspects of the anti-offshore regulation in future research projects on the subject.

\section{References / Список литературы}

Arnold, B. J. (2019) The Evolution of Controlled Foreign Corporation Rules and Beyond. Bulletin for International Taxation. 73 (12), 631-648.

Asen, E. (2020) Corporate tax rates around the world, 2020. The Tax Foundation. (735), 1-18. Available at: https://files.taxfoundation.org/20201208152358/2020-Corporate-Tax-Ratesaround-the-World.pdf [Accessed 02nd September 2021].

Avi-Yonah, R.S. (2005) All of a Piece Throughout - The Four Ages of U.S. International Taxation. Virginia Tax Review. 25 (2), 313-338.

Avi-Yonah, R. S. (2016) Constructive unilateralism: U.S. leadership and international taxation. International Tax Journal. 42 (2), 17-24.

Beller, G. C. (2018) GILTI: Made in America for European Tax Unilateral Measures \& Cooperative Surplus in the International Tax Competition Game. Virginia Tax Review. 38(271(2019)). Available at SSRN: https://ssrn.com/abstract=3273085 [Accessed 02nd September 2021].

Bogdan, M. (2013) Concise Introduction to Comparative Law. Groningen, Europa Law Publishing. Bueltel, B.L. \& Duxbury, A. (2021). Feeling GILTI: Tax Strategies for US Multinational Corporations to Navigate the Tax Cuts and Jobs Act. ATA Journal of Legal Tax Research. $19(1), 1-29$.

Drake, K. D., Lusch, S.J. \& Stekelberg, J. (2019) Does Tax Risk Affect Investor Valuation of Tax Avoidance? Journal of Accounting, Auditing \& Finance. 34 (1), 151-176.

Eberle, E.J. (2011) Methodology of Comparative Law. Roger Williams UL Rev. (16), 51-72.

Eden, L. \& Kudrle R.T. (2005) Tax Havens: Renegade States in the International Tax Regime? Law \& Policy. 27 (1), 100-127.

Frolova, E. \& Tsepova E. (2021) Prospects for reforming approaches to the legal status of a Russian resident individual. State and law. (6), 158-172. https://doi.org/10.31857/ S102694520015038-2 (in Russian).

Фролова E.E., Цепова E.A. Перспективы реформирования подходов к наделению физических лиц правовым статусом резидента Российской Федерации // Государство и право. 2021. № 6. С. 158-172. https://doi.org/10.31857/S102694520015038-2

Frolova, E. \& Tsepova, E. (2020) 30 years of currency exchange liberalization in Russia: prospects for abolition restrictions on individual's capital movement. State and law. (4), 108-124. https://doi.org/10.31857/S013207690009240-6 (in Russian).

Фролова E.E., Цепова Е.А. 30 лет валютной либерализации в России: перспективы отмены ограничений на движение капитала физических лиц // Государство и право. 2020. № 4. C. 108 - 124. https://doi.org/10.31857/S013207690009240-6

Joscelyne, M. \& Wentworth-May, M. (2012) The UK's New CFC Regime. Thomson Reuters Practical Law. Available at: https://uk.practicallaw.thomsonreuters.com/0-519-8741?_lrTS= $20171105091356388 \&$ transitionType $=$ Default\&contextData $=\% 28$ sc.Default $\% 29$ [Accessed 03rd September 2021].

Hilling, M. (2013) Justifications and Proportionality: An Analysis of the ECJ's Assessment of National Rules for the Prevention of Tax Avoidance. Intertax. 41(5), 294-307. 
Isenbergh, J. \& Wells, B. (2020) International taxation. $4^{\text {th }}$ Edition. New York, Foundation Press.

Mara, E.R. (2015) Determinants of tax havens. Procedia Economics and Finance. (32), $1638-1646$.

Maydew, J., Marques, J., Porchat de Assis, J. \& Tenenboym, M. (2018) Brazilian Interest on Equity After U.S. Tax Reform. Tax Management International Journal. 47(11), 717. Available at: https://www.trenchrossi.com/wp-content/uploads/2018/11/bloomberg_tax_julianaassis.pdf [Accessed 03rd September 2021].

Meyer, R.A. (2013) Tax transparency. Business Horizons. 56 (5), 543-549.

Morris, M. (2017) The 26 OECD Common Reporting Standard Loopholes. Available at: http://www.the-best-of-both-worlds.com/support-files/oecd-crs-loopholes-report.pdf [Accessed 20th August 2021].

Morten, B. \& Zeume, S. (2018) Corporate Tax Havens and Transparency. The Review of Financial Studies. 31 (4), 1221-1264.

Noked, N. (2018a) Tax Evasion and Incomplete Tax Transparency. Laws. 7 (3), 31. Available at: https://doi.org/10.3390/laws7030031 [Accessed 04th September 2021].

Noked, N. (2018b) FATCA, CRS, and the Wrong Choice of Who to Regulate. Florida Tax Review. (22). Available at https://papers.ssrn.com/sol3/papers.cfm?abstract_id=3143663 [Accessed 02nd September 2021].

Owens, J. (2015) Tax Transparency and BEPS. Journal of Tax Administration. 1 (2), 1-10.

Pistone, P. (2014). Coordinating the Actions of Regional and Global Players during the Shift from Bilateralism to Multilateralism in International Tax Law. World Tax Journal. 6 (1), 3-9.

Pross, A. (2015) How Tax Transparency Went Global - the new automatic exchange standard: from concept to reality. International Tax Review. 25 March 2015. Available at: https://www.internationaltaxreview.com/Article/3439573/How-tax-transparency-went-globalthe-new-automatic-exchange-standard-from-concept-to-reality.html?ArticleId=3439573 [Accessed 02nd September 2021].

Rocha, S.A. (2017) Brazil's International Tax Policy. Editora Lumen Juris.

Rosenblatt, P. (2012) Brazil: CFC Rules Update. Intertax. 40 (4), 279-284.

Rust, A. (2008) CFC Legislation and EC Law. Intertax. 36 (11), 492-501.

Schmidt, P.K. (2016) Taxation of Controlled Foreign Companies in Context of the OECD/G20 Project on Base Erosion and Profit Shifting as well as the EU Proposal for the Anti-Tax Avoidance Directive - An Interim Nordic Assessment. Nordic Tax Journal. (2), 87-112.

Tsepova, E.A. (2020) Individuals' Capital Allocation in Different Jurisdictions Within the Context of International Tax Transparency: Improving the Global Approaches to Financial Regulation. In: Popkova E., Sergi B. (eds.) Scientific and Technical Revolution: Yesterday, Today and Tomorrow. ISC 2019. Lecture Notes in Networks and Systems. T. 129. Springer, Cham. Pp. 1612-1626. https://doi.org/10.1007/978-3-030-47945-9_172

Tsepova, E.A. (2019a) Regulation of tax and currency exchange obligations of individuals, ownings the property abroad. Proceedings of the Institute of State and Law of the RAS. 14 (1), 141-165. (in Russian).

Цепова Е.А. Правовое регулирование налоговых и валютно-правовых обязательств физических лиц - собственников имущества за рубежом // Труды Института государства и права Российской академии наук. 2019. Т. 14. № 1. С. $141-165$.

Tsepova, E.A. (2019b) Participation of individuals in controlled foreign companies: tax legal relations in the Russian Federation. Economic Problems and Legal Practice. 15 (1), 161-165. (in Russian).

Цепова E.A. Участие физических лиц в контролируемых иностранных компаниях: налоговые правоотношения в Российской Федерации // Проблемы экономики и юридической практики. 2019. Т. 15. № 1. С. 161-165. 


\section{About the authors:}

Evgenia E. Frolova - Doctor of Legal Sciences, Honored Lawyer of the Russian Federation, Full Professior, Head of the Department of Civil Law and Procedural Law and Private International Law, Law Institute, Peoples' Friendship University of Russia (RUDN University); 6 Miklukho-Maklaya str., Moscow, 117198, Russian Federation; Full Professior of the Department of theory and history of state and law, Far Eastern Federal University; 10, Ajax Bay, Vladivostok, Russky Island, 690922, Russian Federation

ORCID ID: 0000-0002-1852-0085, Scopus Author ID: 56439998700, SPIN-code: 5471-0740 e-mail: frolova_ee@rudn.ru

Ekaterina A. Tsepova - Candidate of Legal Sciences, Senior Lecturer of the Department of Civil Law and Procedural Law and Private International Law, Law Institute, Peoples' Friendship University of Russia (RUDN University); 6 Miklukho-Maklaya str., Moscow, 117198, Russian Federation

ORCID ID: 0000-0001-8147-7633, SPIN-code: 8221-7585

e-mail: tsepova.ekaterina@gmail.com

\section{Об авторах:}

Фролова Евгения Евгеньевна - доктор юридических наук, Заслуженный юрист Российской Федерации, профессор, заведующая кафедрой гражданского права и процесса и международного частного права, Юридический институт, Российский университет дружбы народов; Российская Федерация, 117198, г. Москва, ул. Миклухо-Маклая, д. 6; профессор кафедры теории и истории государства и права, Юридическая школа, Дальневосточный федеральный университет; Российская Федерация, 690922, г. Владивосток, о-в Русский, п-ов Аякс, д. 10

ORCID ID: 0000-0002-1852-0085, Scopus Author ID: 56439998700, SPIN-код: 5471-0740 e-mail: frolova_ee@rudn.ru

Цепова Екатерина Андреевна - кандидат юридических наук, старший преподаватель, кафедра гражданского права и процесса и международного частного права, Юридический институт, Российский университет дружбы народов; Российская Федерация, 117198, г. Москва, ул. Миклухо-Маклая, д. 6

ORCID ID: 0000-0001-8147-7633, SPIN-код: 8221-7585

e-mail: tsepova.ekaterina@gmail.com 